\title{
Singular Perturbation Method Applied for BVP, IVP and Optimal Control to One Parameter Armature Controlled DC Servo Motor
}

\author{
KISHOR BABU GUNTI * \\ Department of EEE, \\ Gudlavalleru Engineering College, \\ Gudlavalleru, A. P. 521356, \\ INDIA.
SREE KRISHNARAYALU MOVVA Department of EEE, VR Siddhartha Engineering College Vijayawada, Andhra Pradesh 520007, INDIA.

\begin{abstract}
DC servo motor discrete model of one-parameter Singular Perturbation Method (SPM) is enlarged showing zero-order, first-order and second-order approximations. In this paper, a one parameter SPM based two time scale model is considered for evaluation. Now by applying this SPM a real time Boundary Value Problems (BVP), Initial Value Problem (IVP) and Optimal Control Problem (OCP) are premeditated. Such evaluated SPM have a boundary layer correction (BLC) solution and an outer series solution. To improve degenerate solution and to recover initial and boundary conditions a BLC solution of SPM is used. The DC servo-motor control model of second order approximation is carried out for BVP, IVP and OCP. The results thus obtained are presented in comparison to the precise solution. The efficacy of the present model is evaluated in MATLAB environment.
\end{abstract}

Keywords: Discrete one-parameter servo system; optimal control problem; singular perturbation method; boundary layer correction; boundary value problems; initial value problem.

Received: May 13, 2021. Revised: January 17, 2022. Accepted: February 7, 2022. Published: March 5, 2022.

\section{Introduction}

Conventionally the continuous and discrete control systems are modeled based on high order differential equations and difference equations. The order of the system is described by the energy storage elements like time constants, moments of inertia, masses, capacitances and inductances present in the system. Such obtained higher order BVP and optimal solution leads to the usage of shooting method [26]. SPM eases this crisis by repressing the small- parameters. Thus developed SPM is meant to eliminate systems firmness, decreases control system order and results in exact solution fulfilling the set boundary conditions. Time-scale and singularly perturbed systems are same [1-14]. The researchers are aspiring towards discrete control systems [3-6, 9-20] rather than matured continuous control systems $[1,2,7,18,21$ 24]. To study that gap, a DC servomotor with two time scales is considered in this paper. Later the studied model is developed as one parameter Singularly Perturbed System (SPS) for evaluating the discrete control systems [5-20, 25, 26]. Further, SPM based discrete control systems developed as BVP, IVP and OCP with performance index are approximated and extended upto second order.

\section{Discrete One-Parameter Problem}

2.1 Discrete One-Parameter Problem for BVP and IVP:

Here we are considering the two time scale discrete control system described in Fig. 1. One and multi parameter problems in discrete systems are premeditated broadly $[15,16,17]$. We consider slow and fast state variables are $\mathrm{x}_{0}(\mathrm{k})$ and $\mathrm{x}_{1}(\mathrm{k})$ respectively, $\mathrm{u}(\mathrm{k})$ is input variable of step signal, $\varepsilon$ is the small parameter, A and B are state and input matrices and have written state equation from Fig.2 and initial conditions are $\mathrm{x}_{0}(\mathrm{k}=0)=$ $\mathrm{x}_{0}(0)$ and $\mathrm{x}_{1}(\mathrm{k}=0)=\mathrm{x}_{1}(0)$ 


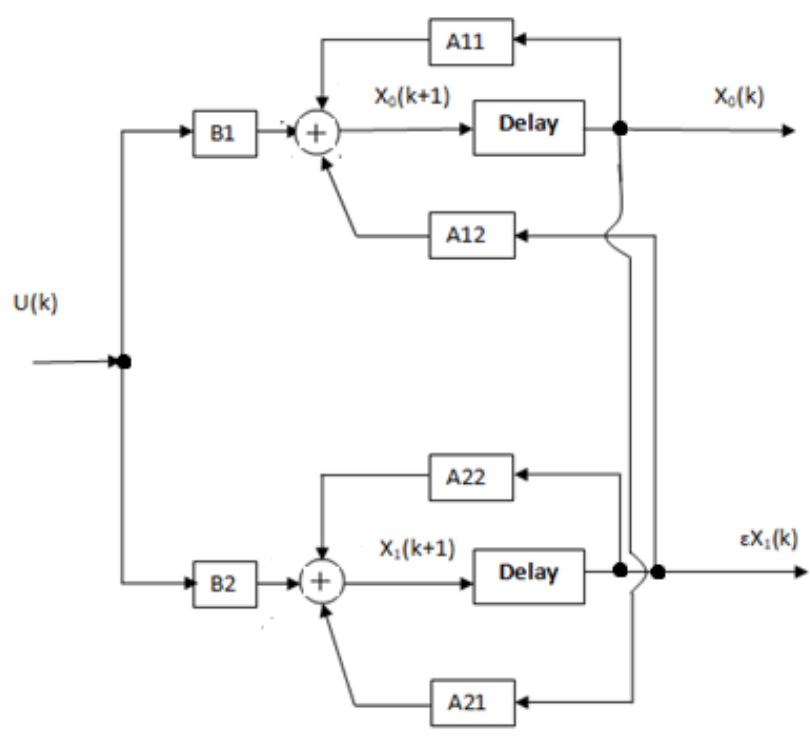

Fig. 1. A linear time invariant two-time-scale system

$$
\left[\begin{array}{c}
\mathrm{x}_{0}(\mathrm{k}+1) \\
\mathrm{x}_{1}(\mathrm{k}+1)
\end{array}\right]=\mathrm{A}\left[\begin{array}{c}
\mathrm{x}_{0}(\mathrm{k}) \\
\varepsilon \mathrm{x}_{1}(\mathrm{k})
\end{array}\right]+\mathrm{Bu}(\mathrm{k})
$$

Where $A=\left[\begin{array}{ll}A_{11} & A_{12} \\ A_{21} & A_{22}\end{array}\right], B=\left[\begin{array}{l}B_{1} \\ B_{2}\end{array}\right]$

In the process of degeneration discard the state variable of $\mathrm{x}_{1}(0)$ for $\varepsilon$ is zero in (1) and initial conditions $\quad \mathrm{x}_{0}^{0}(0)=\mathrm{x}_{0}(0) \quad$ and $\mathrm{x}_{1}^{0}(0) \neq$ $\mathrm{x}_{1}(0)$.Consequentially the reduced system is specified by

$$
\left[\begin{array}{c}
\mathrm{x}_{0}^{0}(\mathrm{k}+1) \\
\mathrm{x}_{1}^{0}(\mathrm{k}+1)
\end{array}\right]=\mathrm{A}\left[\begin{array}{c}
\mathrm{x}_{0}^{0}(\mathrm{k}) \\
0
\end{array}\right]+\mathrm{Bu}(\mathrm{k})
$$

The SPM which formulates the process of recovery of the lost initial conditions is discussed in the next secession.

\subsection{Discrete One-Parameter Problem for OCP:}

Here we are consider the singularly perturbed one-parameter discrete control system (1). The performance index to be minimized is $\mathrm{J}=1 / 2 \sum_{\mathrm{k}=0}^{\mathrm{N}-1}\left[\mathrm{w}^{\prime}(\mathrm{k}) \operatorname{Dw}(\mathrm{k})+\mathrm{u}^{\prime}(\mathrm{k}) \mathrm{Ru}(\mathrm{k})\right]$

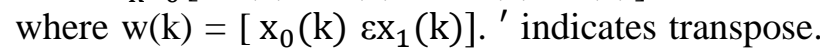
$\mathrm{D}$ is a real positive-semidefinite symmetric matrix of order $\left(\mathrm{n}_{1}+\mathrm{n}_{2}\right) \times\left(\mathrm{n}_{1}+\mathrm{n}_{2}\right)$. $\mathrm{R}$ is real positive-definite symmetric matrix of order $(1 \times 1)$ and $\mathrm{N}$ is a fixed integer indicating the terminal (final) time. Here note that the states are incorporated in an appropriate manner to bring the resulting Two Point Bundary value Problem(TPBVP) into SPS[26]. The Hamiltonian of the problem is

$$
\begin{aligned}
\mathrm{H}(\mathrm{k})=\frac{1}{2} \mathrm{w}^{\prime}(\mathrm{k}) \operatorname{Dw}(\mathrm{k})+\frac{1}{2} \mathrm{u}^{\prime}(\mathrm{k}) \mathrm{Ru}(\mathrm{k}) \\
+\mathrm{p}^{\prime}(\mathrm{k}+1)[\mathrm{A} \mathrm{w}(\mathrm{k})+\mathrm{Bu}(\mathrm{k})]
\end{aligned}
$$

where the co-state vector $\mathrm{p}(\mathrm{k})=\left[\mathrm{p}_{0}(\mathrm{k}) \varepsilon \mathrm{p}_{1}(\mathrm{k})\right]$

Using the results of digital optimal control theory $[18,20-26]$

$$
\begin{aligned}
& \partial \mathrm{H}(\mathrm{k}) /\left(\partial \mathrm{p}_{0}(\mathrm{k}+1)=\mathrm{x}_{0}(\mathrm{k}+1)\right. \\
& \partial \mathrm{H}(\mathrm{k}) /\left(\partial \varepsilon \mathrm{p}_{1}(\mathrm{k}+1)=\mathrm{x}_{1}(\mathrm{k}+1)\right. \\
& \frac{\partial \mathrm{H}(\mathrm{k})}{\partial \mathrm{x}_{0}(\mathrm{k})}=\mathrm{p}_{0}(\mathrm{k}) \\
& \frac{\partial \mathrm{H}(\mathrm{k})}{\partial \mathrm{x}_{1}(\mathrm{k})}=\varepsilon \mathrm{p}_{1}(\mathrm{k}) \\
& \frac{\partial \mathrm{H}(\mathrm{k})}{\partial \mathrm{u}(\mathrm{k})}=0
\end{aligned}
$$

Form (1) and (4), the co-states and states are obtained as

$$
\left[\begin{array}{c}
\mathrm{x}_{0}(\mathrm{k}+1) \\
\mathrm{x}_{1}(\mathrm{k}+1) \\
\mathrm{p}_{0}(\mathrm{k}) \\
\mathrm{p}_{1}(\mathrm{k})
\end{array}\right]=C\left[\begin{array}{c}
\mathrm{x}_{0}(\mathrm{k}) \\
\varepsilon \mathrm{x}_{1}(\mathrm{k}) \\
\mathrm{p}_{0}(\mathrm{k}+1) \\
\varepsilon \mathrm{p}_{1}(\mathrm{k}+1)
\end{array}\right]
$$

$$
\text { Where } \mathrm{C}=\left[\begin{array}{llll}
\mathrm{A}_{11} & \mathrm{~A}_{12} & \mathrm{E}_{11} & \mathrm{E}_{12} \\
\mathrm{~A}_{21} & \mathrm{~A}_{22} & \mathrm{E}_{12}^{\prime} & \mathrm{E}_{22} \\
\mathrm{D}_{11} & \mathrm{D}_{12} & \mathrm{~A}_{11}^{\prime} & \mathrm{A}_{21}^{\prime} \\
\mathrm{D}_{12}^{\prime} & \mathrm{D}_{22} & \mathrm{~A}_{12}^{\prime} & \mathrm{A}_{22}^{\prime}
\end{array}\right]
$$

$\mathrm{E}_{11}=-\mathrm{B}_{1} \mathrm{R}^{-1} \mathrm{~B}_{1}^{\prime}, \mathrm{E}_{12}=-\mathrm{B}_{1} \mathrm{R}^{-1} \mathrm{~B}_{2}^{\prime}, \mathrm{E}_{21}=$ $-\mathrm{B}_{2} \mathrm{R}^{-1} \mathrm{~B}_{1}^{\prime}$ and $\mathrm{E}_{22}=-\mathrm{B}_{2} \mathrm{R}^{-1} \mathrm{~B}_{2}^{\prime}$.

The final conditions of the system (5a) are

$$
\mathrm{P}_{0}(\mathrm{~N})=0 \text { and } \mathrm{P}_{1}(\mathrm{~N})=0
$$

The optimal control is obtained as

$$
\mathrm{u}^{\mathrm{q}}(\mathrm{k})=-\mathrm{R}^{-1} \sum_{\mathrm{j}=0}^{1}\left[\mathrm{~B}_{\mathrm{j}+1}^{\prime} \quad \varepsilon \mathrm{p}_{\mathrm{j}}^{\mathrm{q}-\mathrm{j}}(\mathrm{k}+1)\right], \mathrm{j}=0,1 .
$$

Where $\mathrm{q}$ is the order of approximation.

The set of equations (5) constitutes the open loop optimal control problem. The $2\left(\mathrm{n}_{1}+\mathrm{n}_{2}\right)^{\text {th }}$ order discrete TPBVP represented by (5) is in the singularly perturbed form in the sense that the degenerate TPBVP

$\left[\begin{array}{c}\mathrm{x}_{0}^{00}(\mathrm{k}+1) \\ \mathrm{x}_{1}^{00}(\mathrm{k}+1) \\ \mathrm{p}_{0}^{00}(\mathrm{k}) \\ \mathrm{p}_{1}^{00}(\mathrm{k})\end{array}\right]=\mathrm{C}\left[\begin{array}{c}\mathrm{x}_{0}^{00}(\mathrm{k}) \\ 0 \\ \mathrm{p}_{0}^{00}(\mathrm{k}+1) \\ 0\end{array}\right]$

Obtained by suppressing the small parameters $\varepsilon$ in (5a) is of order $2 n_{1}$ and can satisfy the boundary conditions

$\mathrm{x}_{0}^{00}(\mathrm{k}=0)=\mathrm{x}_{0}(0)$ and $\mathrm{p}_{0}^{00}(\mathrm{k}=\mathrm{N})=\mathrm{p}_{0}(\mathrm{~N})$

In general, the other boundary conditions are $\mathrm{x}_{1}^{00}(\mathrm{k}=0) \neq \mathrm{x}_{1}(0)$ and $\mathrm{p}_{1}^{00}(\mathrm{k}=\mathrm{N}) \neq \mathrm{p}_{1}(\mathrm{~N})$ 
That is the boundary conditions $\mathrm{x}_{1}(0)$ and $\mathrm{p}_{1}(\mathrm{~N})$ are lost during the time spent degeneration and the deficiency of these boundary conditions adds to the presence of boundary layers at initial and terminal points. The $2 \mathrm{n}_{2}$ boundary conditions lost during the time spent degeneration are recuperated by the accompanying particular strategy which gives a approximate answer for the stiff/hardened TPBVP addressed by (5c). Subsequently it results in a problematic control.

\section{Singular Perturbation Method}

SPM consists of two solutions, the outer and boundary layer solution. The initial and boundary conditions of SPM, recovers the fast variable in the discrete control systems. The stiffed small parameter ' $\varepsilon$ ' results in outer solution. Then boundary layers are produced due to loss of fast variable and to improve the solution [15- 17, 2026]. First start the flow chart with degenerate solution and then to zero-order solution to improve it as show in Fig. 3 and 4. The outer and BLC solutions are obtained from the respective equations and conditions. The zero-order solution is obtained with total series solution (TSS) addition approximation of outer and BLC solution. This is further enhanced and approximated from first to higher order.

\subsection{Singular perturbation method for IVP}

The outer series solution with asymptotic power series expansions, we gain a set of equations for the zero-order, first-order and second-order approximations. Then formulate boundary layer corrections to enhance the degenerate solution ensuring unique boundary layer solution[15]. Then add them according to total series solution to get the order of solutions which satisfy the given initial conditions as show in Fig. 3.

\subsection{Singular perturbation method for BVP}

We are taking into consideration of two modes of stable system. Here consider first mode is slow and second mode is fast mode, the boundary layers are occurred to stable fast mode at initial point $[16,17]$. Now the problem has become two point BVP (TPBVP) which is as show in Fig. 2. Then add them according to total series solution to get the order of solutions which satisfy the given initial and boundary conditions as show in Fig. 3.

\subsection{Singular perturbation method for OCP}

Algorithm is similar to the SPM of a TPBVP of discrete control systems as the formulation of this optimal control problem results in TPBVP [20, 25,
26]. For a specific order of approximate solution, first track down the external answer for states and co-states. Then, at that point add the BLC comparing to the most singular transformation. Proceed with this cycle lastly add the BLC comparing to the most singular transformation. When a specific order of solution is gotten for states and co-states utilizing total series solution, then obtain the corresponding suboptimal control using control law and asymptotic correctness [28-30].

\section{Application of Discrete One Parameter Singular Perturbation Method(DOPSPM)}

\section{Servo Motor Analysis}

The armature controlled DC servo motor may be modeled as

$\left[\begin{array}{c}\dot{x}_{01}(t) \\ \dot{\mathrm{x}}_{02}(\mathrm{t}) \\ \dot{\mathrm{x}}_{1}(\mathrm{t})\end{array}\right]=\left[\begin{array}{ccc}0 & 1 & 0 \\ 0 & -\mathrm{B} / \mathrm{J} & \mathrm{K}_{\mathrm{t}} / \mathrm{J} \\ 0 & -\mathrm{K}_{\mathrm{b}} / \mathrm{L}_{\mathrm{a}} & -\mathrm{R}_{\mathrm{a}} / \mathrm{L}_{\mathrm{a}}\end{array}\right]\left[\begin{array}{c}\mathrm{x}_{01}(\mathrm{t}) \\ \mathrm{x}_{02}(\mathrm{t}) \\ \mathrm{x}_{1}(\mathrm{t})\end{array}\right]+\left[\begin{array}{c}0 \\ 0 \\ 1 / \mathrm{L}_{\mathrm{a}}\end{array}\right] \mathrm{e}_{\mathrm{a}}(\mathrm{t})$

where

$\mathrm{x}_{01}=$ Angular position of rotor

$\mathrm{x}_{02}=$ Angular velocity of rotor

$\mathrm{x}_{1}=$ Armature current

$\mathrm{e}_{\mathrm{a}}=$ Armature voltage

$\mathrm{R}_{\mathrm{a}}=$ Armature resistance

$\mathrm{L}_{\mathrm{a}}=$ Armature inductance

$\mathrm{K}_{\mathrm{b}}=$ Back electromagnetic field constant

$\mathrm{K}_{\mathrm{t}}=$ Torque constant

$\mathrm{J}=$ Moment of inertia of motor-load set

$\mathrm{B}=$ Viscous coefficient of motor-load set

The $125 \mathrm{~V}, 1500 \mathrm{rpm}$ and $3 \mathrm{hp}$ DC servomotor specifications are [27]:

$\mathrm{R}_{\mathrm{a}}=0.6 \Omega, \mathrm{L}_{\mathrm{a}}=6 \mathrm{mH}, \mathrm{K}_{\mathrm{t}}=0.7274, \mathrm{~K}_{\mathrm{b}}=0.6$,

$\mathrm{J}=0.093 \mathrm{kgm}, \mathrm{B}=0.008 \mathrm{~N}-\mathrm{mrad}^{-1} \mathrm{~s}^{-1}$

Obviously armature inductance $L_{a}$ is very small leading to a two-time-scale singularly perturbed system. This continuous system is discretized with a sampling interval of $0.012 \mathrm{sec}$ for first forward difference. The control signal is taken as unit step function. The subsequent system is shown as below:

$\left[\begin{array}{c}\mathrm{x}_{01}(\mathrm{k}+1) \\ \mathrm{x}_{02}(\mathrm{k}+1) \\ \mathrm{x}_{1}(\mathrm{k}+1)\end{array}\right]=\left[\begin{array}{ccc}1.000 & 0.012 & 0.000 \\ 0.000 & 0.999 & 0.0939 \\ 0.000 & -1.200 & -0.200\end{array}\right]\left[\begin{array}{c}\mathrm{x}_{01}(\mathrm{k}) \\ \mathrm{x}_{02}(\mathrm{k}) \\ \mathrm{x}_{1}(\mathrm{k})\end{array}\right]+\left[\begin{array}{c}0.000 \\ 0.000 \\ 2.000\end{array}\right] \mathrm{u}(\mathrm{k})$

Here $\mathrm{x}_{0}=\left\{\mathrm{x}_{01}, \mathrm{x}_{02}\right\}=$ set of slow state variables, $\mathrm{x}_{1}$ represents fast state variables and $u(k)$ is unit step control function. The eigen spectrum of this system $(1.0000 ; 0.8962 ;-0.0973)$

is of the two time scale nature one with fast mode and two slow modes. The one-parameter system 
with above eigen spectrum is represented as shown in equation $(9 \mathrm{c})$.

$\left[\begin{array}{c}\mathrm{x}_{01}(\mathrm{k}+1) \\ \mathrm{x}_{02}(\mathrm{k}+1) \\ \mathrm{x}_{1}(\mathrm{k}+1)\end{array}\right]=\left[\begin{array}{ccc}1.000 & 0.012 & 0.000 \\ 0.000 & 0.999 & 0.939 \\ 0.000 & -1.200 & -2.000\end{array}\right]\left[\begin{array}{c}\mathrm{x}_{01}(\mathrm{k}) \\ \mathrm{x}_{02}(\mathrm{k}) \\ \varepsilon \mathrm{x}_{1}(\mathrm{k})\end{array}\right]+\left[\begin{array}{c}0.000 \\ 0.000 \\ 2.000\end{array}\right] \mathrm{u}(\mathrm{k})$
where $\varepsilon=0.1$

\section{IVP}

The initial conditions are specified at initial point $(\mathrm{k}=0)$

$\mathrm{x}_{01}(0)=1 ; \quad \mathrm{x}_{02}(0)=1 ; \quad \mathrm{x}_{1}(0)=1$.

\section{$B V P$}

The boundary conditions are listed as

$\mathrm{x}_{01}(10)=2 ; \quad \mathrm{x}_{02}(10)=2 ; \quad \mathrm{x}_{1}(0)=1$.

The TPBVP illustrated as $\mathrm{x}_{01}$ and $\mathrm{x}_{02}$ is specified at $\mathrm{k}=10$ and $\mathrm{x}_{1}$ is specified at initial point $(\mathrm{k}=0)$.

The SPM discussed in the present paper solves the BVP and IVP. The exact solution is compared and illustrated with zeroth, first and second-order approximation solutions. When we are drown graphs between state variable $\mathrm{x}(\mathrm{k})$ vs $\mathrm{k}$. By observing the graph it clear including second order solution was reached to exact solution as shown in the Fig. 4 and Fig. 5 for IVP and BVP respectively. The correct values of all solutions were clearly tabulated as shown in the table 1 and table 2 for IVP and BVP respectively.

\section{OCP}

The initial conditions are given as

$$
\mathrm{x}_{01}(0)=1 ; \quad \mathrm{x}_{02}(0)=1 ; \quad \mathrm{x}_{1}(0)=1 .
$$

and the final conditions are $\mathrm{p}_{01}(10)=0 ; \quad \mathrm{p}_{02}(10)=0 ; \quad \mathrm{p}_{1}(10)=0$.

and the performance index

$$
\begin{gathered}
\mathrm{J}=1 / 2 \sum_{\mathrm{k}=0}^{\mathrm{N}-1}\left[\mathrm{w}^{\prime}(\mathrm{k}) \mathrm{DW}(\mathrm{k})+\mathrm{u}^{\prime}(\mathrm{k}) \mathrm{Ru}(\mathrm{k})\right](11) \\
\text { where } \mathrm{R}=1, \mathrm{D}=\left[\begin{array}{lll}
1 & 0 & 0 \\
0 & 1 & 0 \\
0 & 0 & 1
\end{array}\right], \quad \mathrm{w}(\mathrm{k})=\left[\begin{array}{l}
\mathrm{x}_{01}(\mathrm{k}) \\
\mathrm{x}_{02}(\mathrm{k}) \\
\varepsilon \mathrm{x}_{1}(\mathrm{k})
\end{array}\right]
\end{gathered}
$$

The singularly perturbed TPBVP of fourth-order corresponding to (9) is

$\left[\begin{array}{c}\mathrm{x}_{01}(\mathrm{k}+1) \\ \mathrm{x}_{02}(\mathrm{k}+1) \\ \mathrm{x}_{1}(\mathrm{k}+1) \\ \mathrm{p}_{01}(\mathrm{k}) \\ \mathrm{p}_{02}(\mathrm{k}) \\ \mathrm{p}_{1}(\mathrm{k})\end{array}\right]=$

$\left[\begin{array}{cccccc}1.000 & 0.012 & 0.000 & 0.000 & 0.000 & 0.000 \\ 0.000 & 0.999 & 0.939 & 0.000 & 0.000 & 0.000 \\ 0.000 & -1.200 & -2.000 & 0.000 & 0.000 & 4.000 \\ 1.000 & 0.000 & 0.000 & 0.999 & 0.000 & 0.000 \\ 0.000 & 1.000 & 0.000 & 0.012 & 1.000 & -1.200 \\ 0.000 & 0.000 & 1.000 & 0.000 & 0.939 & -2.000\end{array}\right]\left[\begin{array}{c}\mathrm{x}_{01}(\mathrm{k}) \\ \mathrm{x}_{02}(\mathrm{k}) \\ \mathrm{x}_{1}(\mathrm{k}) \\ \mathrm{p}_{01}(\mathrm{k}+1) \\ \mathrm{p}_{02}(\mathrm{k}+1) \\ \mathrm{p}_{1}(\mathrm{k}+1)\end{array}\right]$

Utilizing the singularly perturbed strategy created in the past segment, the degenerate, zero, first and second-order solutions are assessed and contrasted and the optimal siolution in table 3 and table 4 . Perceptions from this table are

$>$ The degenerate solution, acquired by making $\varepsilon$ equivalent to focus in (6), can't fulfill the limit states of quick state and co-state determined as $\mathrm{x}_{1}(0)=1$ and $\mathrm{p}_{1}(10)=0$.

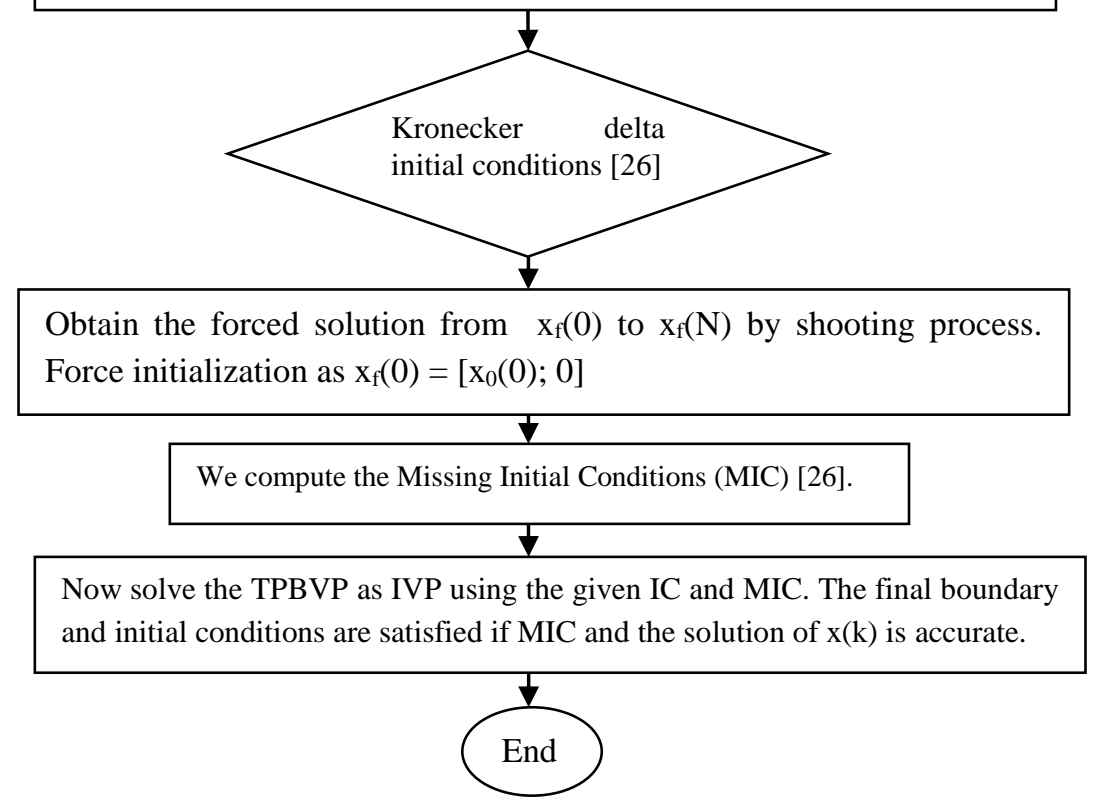

Fig. 2. Flow Chart for TPBVP 


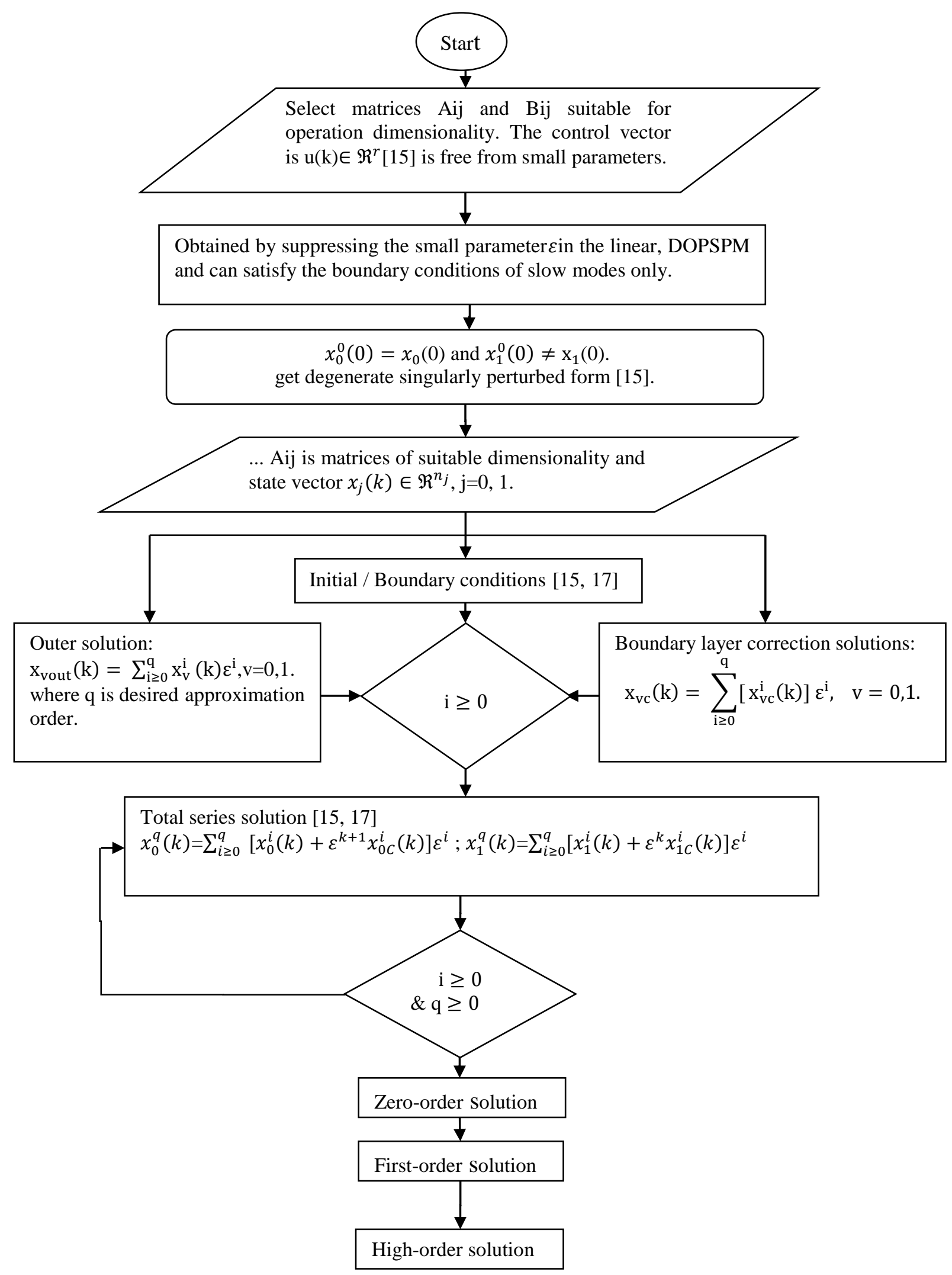

Fig. 3. Flow Chart for Singular Perturbation Methods 
The zero-request arrangement, gotten from (9), joins BLCs and recuperates these limit conditions $\mathrm{x}_{1}(0)$ and $\mathrm{p}_{1}(10)$.

The first-order solution further develops the zeroorder solution. The second-order solution further develops the main request solution and is a lot nearer to the optimal solution. The optimal solution of the fourth-order singularly perturbed discrete TPBVP given by (5a) is acquired by the technique for integral capacities recommended for consistent 'hardened' issues. This requires a mathematical calculation to be carried out on a computerized PC [26]. Then again, by utilizing the present SPM, the different series solutions are effectively acquired as the firmness is taken out and simultaneously are exceptionally near the optimal solution. Subsequently it is seen that the singularly perturbed strategy decreases the request as well as eliminates the 'hardness' of the issue. This can be proven from the eigen values of full and ruffian optimal control system.

Eigen values of full optimal control system

$=\{10.7812 ; 1.2292 ; 1.0101 ; 0.9891 ; 0.8130 ;-$ $0.0921\}$

Eigenvalues of degenerate optimal control system

$=\{1.0010 ; 1.0000 ; 1.0000 ; 0.9990\}$

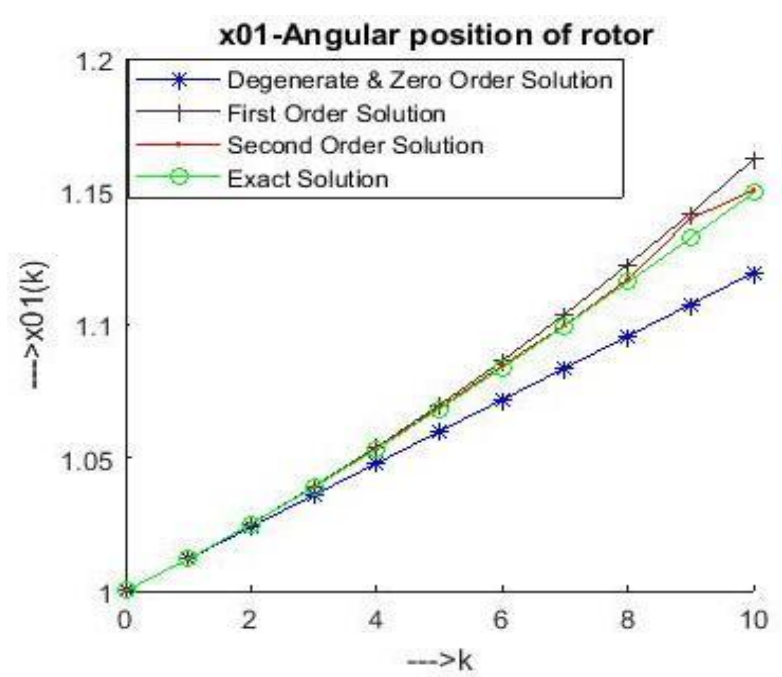

Fig. 4(a). Comparisons of various series solution of $\mathrm{x}_{01} / \mathrm{x} 01$ with exact solution for IVP

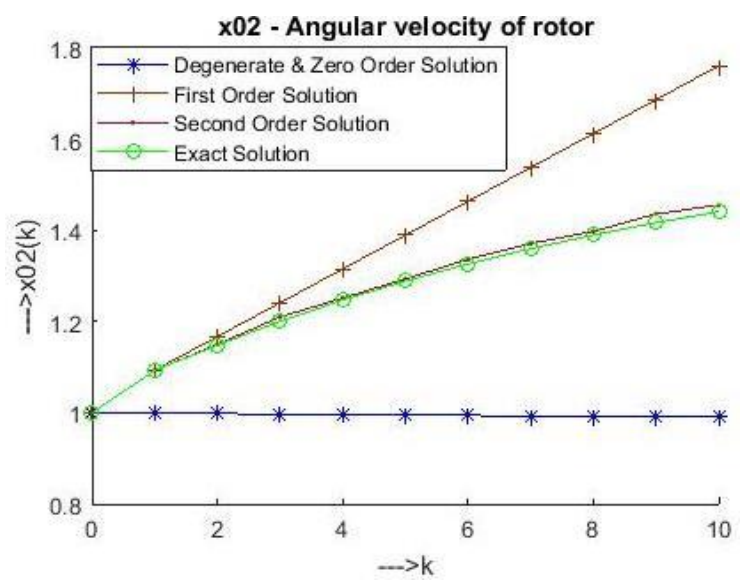

Fig. 4(b). Comparisons of various series solution of $\mathrm{x}_{02} / \mathrm{x} 02$ with exact solution for IVP

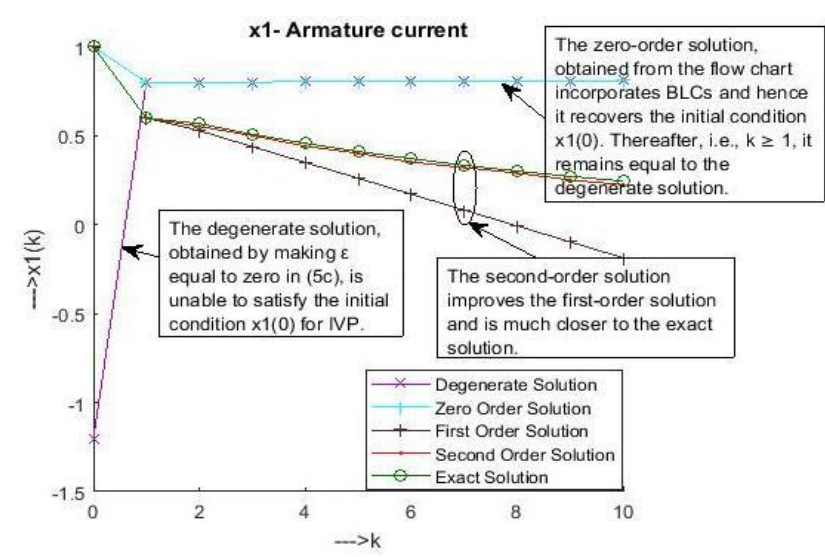

Fig. 4(c). Comparisons of various series solution of $\mathrm{x}_{1} / \mathrm{x} 1$ with exact solution for IVP

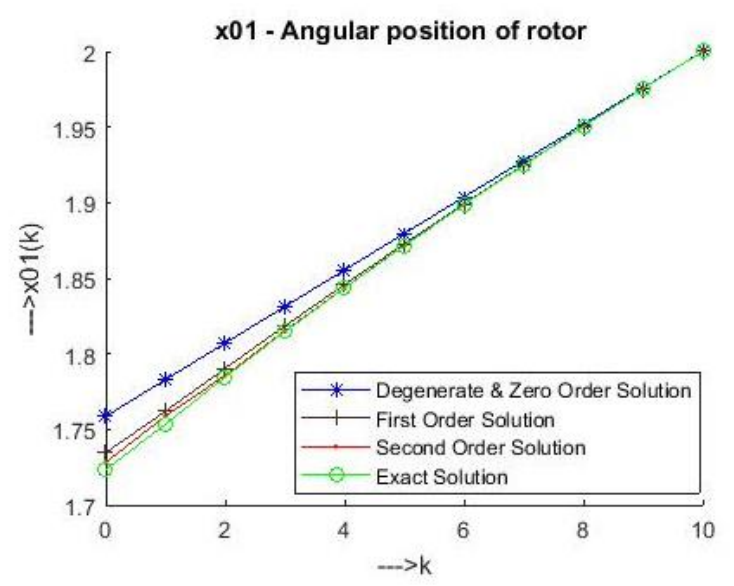

Fig. 5(a). Comparisons of various series solution of $\mathrm{x}_{01} / \mathrm{x} 01$ with exact solution for $\mathrm{BVP}$ 


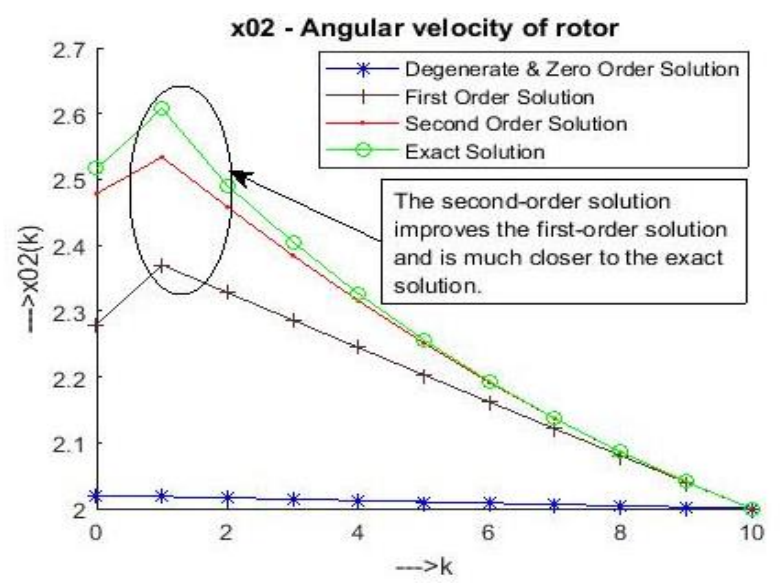

Fig. 5(b). Comparisons of various series solution of $\mathrm{x}_{02} / \mathrm{x} 02$ with exact solution for BVP

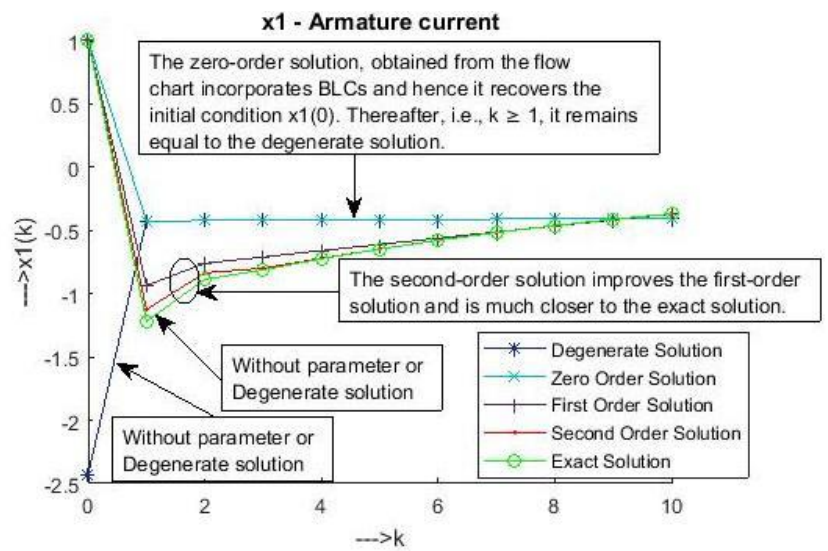

Fig. 5(c). Comparisons of various series solution of $\mathrm{x}_{1} / \mathrm{x} 1$ with exact solution for BVP

Table 1. Comparison illustration of IVP exact solution with various prior series solutions.

\begin{tabular}{|c|c|c|c|c|c|}
\hline $\mathrm{x}(\mathrm{k})$ & $\begin{array}{c}\text { Degener } \\
\text { ate } \\
\text { Solution }\end{array}$ & $\begin{array}{c}\text { Zero } \\
\text { Order } \\
\text { Solutio } \\
\mathrm{n}\end{array}$ & $\begin{array}{c}\text { First } \\
\text { Order } \\
\text { Solutio } \\
\mathrm{n}\end{array}$ & $\begin{array}{c}\text { Second } \\
\text { Order } \\
\text { Solutio } \\
\mathrm{n}\end{array}$ & $\begin{array}{c}\text { Exact } \\
\text { Solutio } \\
\mathrm{n}\end{array}$ \\
\hline $\mathrm{x} 01_{1}(0)$ & 1 & 1 & 1 & 1 & 1 \\
$\mathrm{x}_{02}(0)$ & 1 & 1 & 1 & 1 & 1 \\
$\mathrm{x}_{1}(0)$ & -1.2012 & 1 & 1 & 1 & 1 \\
\hline $\mathrm{x}_{01}(1)$ & 1.0120 & 1.0120 & 1.0120 & 1.0120 & 1.0120 \\
$\mathrm{x}_{02}(1)$ & 0.9990 & 0.9990 & 1.0929 & 1.0929 & 1.0929 \\
$\mathrm{x}_{1}(1)$ & 0.8000 & 0.8000 & 0.6000 & 0.6000 & 0.6000 \\
\hline $\mathrm{x}_{01}(2)$ & 1.0240 & 1.0240 & 1.0251 & 1.0251 & 1.0251 \\
$\mathrm{x}_{02}(2)$ & 0.9980 & 0.9980 & 1.1669 & 1.1499 & 1.1481 \\
$\mathrm{x}_{1}(2)$ & 0.8012 & 0.8012 & 0.5285 & 0.5530 & 0.5685 \\
\hline $\mathrm{x}_{01}(3)$ & 1.0360 & 1.0360 & 1.0392 & 1.0389 & 1.0389 \\
$\mathrm{x}_{02}(3)$ & 0.9970 & 0.9970 & 1.2410 & 1.2097 & 1.2004 \\
$\mathrm{x}_{1}(3)$ & 0.8024 & 0.8024 & 0.4394 & 0.5009 & 0.5085 \\
\hline $\mathrm{x}_{01}(4)$ & 1.0479 & 1.0479 & 1.0540 & 1.0535 & 1.0533 \\
$\mathrm{x}_{02}(4)$ & 0.9960 & 0.9960 & 1.3151 & 1.2314 & 1.2469 \\
$\mathrm{x}_{1}(4)$ & 0.8036 & 0.8036 & 0.3503 & 0.4425 & 0.4578 \\
\hline $\mathrm{x}_{01}(5)$ & 1.0599 & 1.0599 & 1.0698 & 1.0689 & 1.0683 \\
$\mathrm{x}_{02}(5)$ & 0.9950 & 0.9950 & 1.3892 & 1.2931 & 1.2887 \\
$\mathrm{x}_{1}(5)$ & 0.8048 & 0.8048 & 0.2612 & 0.4022 & 0.4121 \\
\hline $\mathrm{x} 01_{01}(6)$ & 1.0718 & 1.0718 & 1.0864 & 1.0847 & 1.0837 \\
$\mathrm{x}_{02}(6)$ & 0.9940 & 0.9940 & 1.4634 & 1.3563 & 1.3261 \\
$\mathrm{x}_{1}(6)$ & 0.8060 & 0.8060 & 0.1720 & 0.3521 & 0.3712 \\
\hline
\end{tabular}

\begin{tabular}{|c|c|c|c|c|c|}
\hline $\mathrm{X}_{01}(7)$ & 1.0837 & 1.0837 & 1.1040 & 1.0999 & 1.0996 \\
$\mathrm{x}_{02}(7)$ & 0.9930 & 0.9930 & 1.5376 & 1.3812 & 1.3596 \\
$\mathrm{x}_{1}(7)$ & 0.8072 & 0.8072 & 0.0827 & 0.3220 & 0.3345 \\
\hline $\mathrm{x}_{01}(8)$ & 1.0957 & 1.0957 & 1.1225 & 1.1171 & 1.1160 \\
$\mathrm{x}_{02}(8)$ & 0.9920 & 0.9920 & 1.6119 & 1.3976 & 1.3897 \\
$\mathrm{x}_{1}(8)$ & 0.8084 & 0.8084 & -0.0066 & 0.3110 & 0.3016 \\
\hline $\mathrm{X}_{01}(9)$ & 1.1076 & 1.1076 & 1.1418 & 1.1398 & 1.1326 \\
$\mathrm{x}_{02}(9)$ & 0.9910 & 0.9910 & 1.6862 & 1.4357 & 1.4166 \\
$\mathrm{X}_{1}(9)$ & 0.8096 & 0.8096 & -0.0959 & 0.2315 & 0.2721 \\
\hline $\mathrm{x}_{1}(10)$ & 1.1195 & 1.1195 & 1.1621 & 1.1505 & 1.1496 \\
$\mathrm{X}_{02}(10)$ & 0.9900 & 0.9900 & 1.7605 & 1.4554 & 1.4407 \\
$\mathrm{X}_{1}(10)$ & 0.8108 & 0.8108 & -0.1853 & 0.2253 & 0.2457 \\
\hline
\end{tabular}

Table 2. Comparison illustration of BVP exact solution with various prior series solutions

\begin{tabular}{|c|c|c|c|c|c|}
\hline $\mathrm{x}(\mathrm{k})$ & $\begin{array}{c}\text { Degene } \\
\text { rate } \\
\text { Solutio } \\
n\end{array}$ & $\begin{array}{c}\text { Zero } \\
\text { Order } \\
\text { Solutio } \\
n\end{array}$ & $\begin{array}{c}\text { First } \\
\text { Order } \\
\text { Solutio } \\
n\end{array}$ & $\begin{array}{c}\text { Second } \\
\text { Order } \\
\text { Solutio } \\
n\end{array}$ & $\begin{array}{c}\text { Exact } \\
\text { Solution }\end{array}$ \\
\hline $\mathrm{x}_{01}(0)$ & 1.7586 & 1.7586 & 1.7346 & 1.7281 & 1.7233 \\
\hline $\mathrm{X}_{02}(0)$ & 2.0201 & 2.0201 & 2.2785 & 2.4785 & 2.5162 \\
\hline $\mathrm{x}_{1}(0)$ & -2.4265 & 1.0000 & 1.0000 & 1.0000 & 1.0000 \\
\hline $\mathrm{X}_{01}(1)$ & 1.7829 & 1.7829 & 1.7620 & 1.7604 & 1.7535 \\
\hline $\mathrm{x}_{02}(1)$ & 2.0180 & 2.0180 & 2.3701 & 2.5338 & 2.6076 \\
\hline $\mathrm{X}_{1}(1)$ & -0.4241 & -0.4241 & -0.9342 & -1.1242 & -1.2195 \\
\hline $\mathrm{X} 01(2)$ & 1.8071 & 1.8071 & 1.7904 & 1.7856 & 1.7847 \\
\hline X02(2) & 2.0160 & 2.0160 & 2.3279 & 2.4581 & 2.4905 \\
\hline $\mathrm{x}_{1}(2)$ & -0.4217 & -0.4217 & -0.7593 & -0.8348 & -0.8852 \\
\hline $\mathrm{x}_{01}(3)$ & 1.8313 & 1.8313 & 1.8184 & 1.8151 & 1.8146 \\
\hline $\mathrm{x}_{02}(3)$ & 2.0140 & 2.0140 & 2.2860 & 2.3843 & 2.4049 \\
\hline $\mathrm{x}_{1}(3)$ & -0.4192 & -0.4192 & -0.7091 & -0.7978 & -0.8115 \\
\hline $\mathrm{x}_{01}(4)$ & 1.8554 & 1.8554 & 1.8458 & 1.8437 & 1.8435 \\
\hline X02(4) & 2.0120 & 2.0120 & 2.2443 & 2.3154 & 2.3262 \\
\hline $\mathrm{x}_{1}(4)$ & -0.4168 & -0.4168 & -0.6593 & -0.7194 & -0.7235 \\
\hline $\mathrm{x}_{01}(5)$ & 1.8796 & 1.8796 & 1.8727 & 1.8715 & 1.8714 \\
\hline $\mathrm{X}_{02}(5)$ & 2.0100 & 2.0100 & 2.2029 & 2.2511 & 2.2560 \\
\hline $\mathrm{x}_{1}(5)$ & -0.4144 & -0.4144 & -0.6098 & -0.6466 & -0.6468 \\
\hline $\mathrm{x} 01(6)$ & 1.9037 & 1.9037 & 1.8992 & 1.8985 & 1.8985 \\
\hline $\mathrm{x}_{02}(6)$ & 2.0080 & 2.0080 & 2.1618 & 2.1916 & 2.1930 \\
\hline $\mathrm{x}_{1}(6)$ & -0.4120 & -0.4120 & -0.5606 & -0.5774 & -0.5778 \\
\hline $\mathrm{x}_{01}(7)$ & 1.9278 & 1.9278 & 1.9251 & 1.9248 & 1.9248 \\
\hline $\mathrm{x}_{02}(7)$ & 2.0060 & 2.0060 & 2.1210 & 2.1364 & 2.1365 \\
\hline $\mathrm{x}_{1}(7)$ & -0.4096 & -0.4096 & -0.5118 & -0.5158 & -0.5160 \\
\hline $\mathrm{x} 01(8)$ & 1.9519 & 1.9519 & 1.9506 & 1.9505 & 1.9504 \\
\hline $\mathrm{x} 02(8)$ & 2.0040 & 2.0040 & 2.0804 & 2.0856 & 2.0859 \\
\hline $\mathrm{x}_{1}(8)$ & -0.4072 & -0.4072 & -0.4632 & -0.4618 & -0.4606 \\
\hline $\mathrm{x}_{01}(9)$ & 1.9759 & 1.9759 & 1.9755 & 1.9755 & 1.9755 \\
\hline $\mathrm{X}_{02}(9)$ & 2.0020 & 2.0020 & 2.0401 & 2.0404 & 2.0406 \\
\hline $\mathrm{x}_{1}(9)$ & -0.4048 & -0.4048 & -0.4150 & -0.4113 & -0.4110 \\
\hline $\mathrm{X}_{01}(10)$ & 2.0000 & 2.0000 & 2.0000 & 2.0000 & 2.0000 \\
\hline $\mathrm{X} 02(10)$ & 2.0000 & 2.0000 & 2.0000 & 2.0000 & 2.0000 \\
\hline $\mathrm{x}_{1}(10)$ & -0.4024 & -0.4024 & -0.3681 & -0.3666 & -0.3665 \\
\hline
\end{tabular}

Table 3. Comparison of various series sub-optimal solutions with the optimal solution

\begin{tabular}{|c|c|c|c|c|c|}
\hline $\mathrm{x}(\mathrm{k})$ & $\begin{array}{c}\text { Degener } \\
\text { ate } \\
\text { Solution }\end{array}$ & $\begin{array}{c}\text { Zero } \\
\text { Order } \\
\text { Solution }\end{array}$ & $\begin{array}{c}\text { First } \\
\text { Order } \\
\text { Solutio } \\
\mathrm{n}\end{array}$ & $\begin{array}{c}\text { Second } \\
\text { Order } \\
\text { Solutio } \\
\mathrm{n}\end{array}$ & $\begin{array}{c}\text { Optimal } \\
\text { Solution }\end{array}$ \\
\hline $\mathrm{x}_{01}(0)$ & 1.0000 & 1.0000 & 1.0000 & 1.0000 & 1.0000 \\
$\mathrm{x}_{2}(0)$ & 1.0000 & 1.0000 & 1.0000 & 1.0000 & 1.0000 \\
$\mathrm{x} 1(0)$ & -1.2022. & 1.0000 & 1.0000 & 1.0000 & 1.0000 \\
$\mathrm{p}_{01}(0)$ & 10.5375 & 10.5385 & 10.4532 & 10.4295 & 10.4177 \\
$\mathrm{p}_{02}(0)$ & 10.4888 & 10.4898 & 6.3825 & 5.9598 & 5.2907 \\
\hline
\end{tabular}




\begin{tabular}{|c|c|c|c|c|c|}
\hline $\begin{array}{l}\mathrm{p}_{1}(0) \\
\mathrm{u}(0)\end{array}$ & $\begin{array}{l}8.8133 \\
0.0000\end{array}$ & $\begin{array}{l}8.8123 \\
0.0000 \\
\end{array}$ & $\begin{array}{r}4.1386 \\
-1.5571 \\
\end{array}$ & $\begin{array}{c}4.0074 \\
-0.6312 \\
\end{array}$ & $\begin{array}{r}3.7934 \\
-0.5352 \\
\end{array}$ \\
\hline $\mathrm{x}_{01}(1)$ & 1.0130 & 1.0120 & 1.0120 & 1.0120 & 1.0120 \\
\hline $\mathrm{X}_{02}(1)$ & 0.9990 & 0.9990 & 1.0929 & 1.0929 & 1.0929 \\
\hline X1(1) & -1.2000 & -1.2000 & -1.9586 & -2.2596 & -2.4704 \\
\hline $\mathrm{p}_{01}(1)$ & 9.5385 & 9.5385 & 9.4657 & 9.4251 & 9.4177 \\
\hline $\mathrm{p}_{02}(1)$ & 9.3847 & 9.3847 & 4.9993 & 4.5943 & 4.5034 \\
\hline $\mathrm{p}_{1}(1)$ & 7.7859 & 7.7859 & 3.1562 & 2.9502 & 2.6762 \\
\hline $\mathrm{u}(1)$ & 0.0000 & 0.0000 & -1.3542 & -0.6125 & -0.4302 \\
\hline $\mathrm{X} 01(2)$ & 1.0239 & 1.0239 & 1.0250 & 1.0251 & 1.0251 \\
\hline $\mathrm{X}_{02}(2)$ & 0.9980 & 0.9980 & 0.9791 & 0.8701 & 0.8598 \\
\hline $\mathrm{x}_{1}(2)$ & -1.19880 & -1.19880 & -1.4448 & -1.5948 & -1.6779 \\
\hline $\mathrm{p}_{01}(2)$ & 8.5265 & 8.5265 & 8.4537 & 8.4130 & 8.4057 \\
\hline $\mathrm{p}_{02}(2)$ & 8.2917 & 8.2917 & 4.6202 & 3.6142 & 3.5713 \\
\hline $\mathrm{p}_{1}(2)$ & 6.7710 & 6.7710 & 3.0628 & 2.7486 & 2.1513 \\
\hline $\mathrm{u}(2)$ & 0.0000 & 0.0000 & -1.1535 & -0.5529 & -0.3355 \\
\hline $\mathrm{x}_{01}(3)$ & 1.0359 & 1.0359 & 1.0358 & 1.0354 & 1.0354 \\
\hline $\mathrm{x}_{02}(3)$ & 0.9970 & 0.9970 & 0.8655 & 0.7455 & 0.7014 \\
\hline $\mathrm{x}_{1}(3)$ & -1.19760 & -1.19760 & -1.3089 & -1.3487 & -1.3673 \\
\hline $\mathrm{p}_{01}(3)$ & 7.5025 & 7.5025 & 7.4286 & 7.4097 & 7.3806 \\
\hline $\mathrm{p}_{02}(3)$ & 7.2109 & 7.2109 & 3.2463 & 3.0946 & 2.8271 \\
\hline $\mathrm{p}_{1}(3)$ & 5.7677 & 5.7677 & 2.7648 & 2.0644 & 1.6777 \\
\hline $\mathrm{u}(3)$ & 0.0000 & 0.0000 & -0.9552 & -0.4317 & -0.2569 \\
\hline $\mathrm{x} 01(4)$ & 1.0479 & 1.0479 & 1.0472 & 1.0440 & 1.0438 \\
\hline $\mathrm{X}_{02}(4)$ & 0.9960 & 0.9960 & 0.7522 & 0.6227 & 0.5723 \\
\hline X1(4) & -1.1964 & -1.1964 & -1.1158 & -1.1005 & -1.0820 \\
\hline $\mathrm{p}_{01}(4)$ & 6.4666 & 6.4666 & 6.3918 & 6.3719 & 6.3452 \\
\hline $\mathrm{p}_{02}(4)$ & 6.1424 & 6.1424 & 2.8790 & 2.5074 & 2.2059 \\
\hline $\mathrm{p}_{1}(4)$ & 4.7762 & 4.7762 & 2.1586 & 1.8599 & 1.2845 \\
\hline $\mathrm{u}(4)$ & 0.0000 & 0.0000 & -0.7593 & -0.3513 & -0.1903 \\
\hline $\mathrm{X}_{01}(5)$ & 1.0598 & 1.0598 & 1.0565 & 1.0515 & 1.0507 \\
\hline $\mathrm{X} 02(5)$ & 0.9950 & 0.9950 & 0.6391 & 0.5713 & 0.4701 \\
\hline $\mathrm{x}_{1}(5)$ & -1.1952 & -1.1952 & -1.1020 & -1.9725 & -0.8510 \\
\hline $\mathrm{p}_{01}(5)$ & 5.4186 & 5.4186 & 5.3444 & 5.3149 & 5.3014 \\
\hline $\mathrm{p}_{02}(5)$ & 5.0865 & 5.0865 & 1.9867 & 1. 8065 & 1.6858 \\
\hline $\mathrm{p}_{1}(5)$ & 3.7966 & 3.7966 & 1.7568 & 1.2087 & 0.9515 \\
\hline $\mathrm{u}(5)$ & 0.0000 & 0.0000 & -0.5658 & -0.2096 & -0.1332 \\
\hline $\mathrm{x}_{01}(6)$ & 1.0718 & 1.0718 & 1.0639 & 1.0598 & 1.0563 \\
\hline $\mathrm{x}_{02}(6)$ & 0.9940 & 0.9940 & 0.5262 & 0.4759 & 0.3897 \\
\hline $\mathrm{x}_{1}(6)$ & -1.1940 & -1.1940 & -0.9958 & -0.7950 & -0.6604 \\
\hline $\mathrm{p}_{01}(6)$ & 4.3588 & 4.3588 & 4.2882 & 4.2698 & 4.2506 \\
\hline $\mathrm{p}_{02}(6)$ & 4.0432 & 4.0432 & 1.4679 & 1.3677 & 1.2459 \\
\hline $\mathrm{p}_{1}(6)$ & 2.8290 & 2.8290 & 1.0481 & 0.6489 & 0.6662 \\
\hline $\mathrm{u}(6)$ & 0.0000 & 0.0000 & -0.3747 & -0.1789 & -0.0834 \\
\hline $\mathrm{x} 01(7)$ & 1.0837 & 1.0837 & 1.0702 & 1.0653 & 1.0610 \\
\hline $\mathrm{x}_{02}(7)$ & 0.9930 & 0.9930 & 0.4136 & 0.4003 & 0.3273 \\
\hline $\mathrm{x}_{1}(7)$ & -1.1928 & -1.1928 & -0.7058 & -0.6749 & -0.5025 \\
\hline $\mathrm{p}_{01}(7)$ & 3.2869 & 3.2869 & 3.2242 & 3.2200 & 3.1943 \\
\hline $\mathrm{p}_{02}(7)$ & 3.0128 & 3.0128 & 1.0305 & 0.9746 & 0.8688 \\
\hline $\mathrm{p}_{1}(7)$ & 1.8736 & 1.8736 & 0.8947 & 0.4084 & 0.4173 \\
\hline $\mathrm{u}(7)$ & 0.0000 & 0.0000 & -0.1861 & -0.1318 & -0.0395 \\
\hline $\mathrm{x}_{01}(8)$ & 1.0956 & 1.0956 & 1.0752 & 1.0717 & 1.0649 \\
\hline $\mathrm{x}_{02}(8)$ & 0.9920 & 0.9920 & 0.3012 & 0.2926 & 0.2798 \\
\hline $\mathrm{x}_{1}(8)$ & -1.1916 & -1.1916 & -0.5689 & -0.5007 & -0.3713 \\
\hline $\mathrm{p}_{01}(8)$ & 2.2032 & 2.2032 & 2.1540 & 2.1453 & 2.1332 \\
\hline $\mathrm{p}_{02}(8)$ & 1.9953 & 1.9953 & 0.9031 & 0.6958 & 0.5401 \\
\hline $\mathrm{p}_{1}(8)$ & 0.9305 & 0.9305 & 0.6591 & 0.1494 & 0.1976 \\
\hline $\mathrm{u}(8)$ & 0.0000 & 0.0000 & 0.0000 & -0.0358 & 0.0050 \\
\hline $\mathrm{x}_{01}(9)$ & 1.1075 & 1.1075 & 1.0787 & 1.0702 & 1.0683 \\
\hline $\mathrm{X}_{02}(9)$ & 0.9910 & 0.9910 & 0.2990 & 0.2607 & 0.2446 \\
\hline $\mathrm{x}_{1}(9)$ & -1.1904 & -1.1904 & -0.4085 & -0.2325 & -0.2514 \\
\hline $\mathrm{p}_{01}(9)$ & 1.1075 & 1.1075 & 1.0787 & 1.0716 & 1.0683 \\
\hline $\mathrm{p}_{02}(9)$ & 0.9910 & 0.9910 & 0.1891 & 0.2259 & 0.2446 \\
\hline $\mathrm{p}_{1}(9)$ & 0.0000 & 0.0000 & 0.1790 & 0.0075 & -0.0251 \\
\hline $\mathrm{u}(9)$ & 0.0000 & 0.0000 & 0.0000 & 0.0000 & 0.0000 \\
\hline $\mathrm{X}_{01}(10)$ & 1.1194 & 1.1194 & 1.0910 & 1.0910 & 1.0712 \\
\hline
\end{tabular}

\begin{tabular}{|c|c|c|c|c|c|}
\hline $\mathrm{X}_{02}(10)$ & 0.9900 & 0.9900 & 0.2770 & 0.2395 & 0.2208 \\
$\mathrm{X}_{1}(10)$ & -1.1892 & -1.1892 & -0.3715 & -0.2007 & -0.2433 \\
$\mathrm{p}_{01}(10)$ & 0.0000 & 0.0000 & 0.0000 & 0.0000 & 0.0000 \\
$\mathrm{p}_{02}(10)$ & 0.0000 & 0.0000 & 0.0000 & 0.0000 & 0.0000 \\
$\mathrm{p}_{1}(10)$ & -0.0015 & 0.0000 & 0.0000 & 0.0000 & 0.0000 \\
\hline
\end{tabular}

Table 4. Comparison of various series sub-optimal solutions with the optimal solution

\begin{tabular}{|c|c|c|}
\hline S. No. & \multicolumn{2}{|c|}{ Performance Index(PI) } \\
\hline 1 & Degenerate Solution & 17.3087 \\
\hline 2 & Zero Order Solution & 17.3087 \\
\hline 3 & First Order Solution & 14.5304 \\
\hline 4 & Second Order Solution & 13.8785 \\
\hline 5 & Optimal Solution & 13.7855 \\
\hline
\end{tabular}

\section{Conclusion}

Singular perturbation methodology in discrete control systems is being developed for one parameter discrete systems with two time scales. An armature controlled DC servo system is taken as one parameter system as armature inductance is very small giving rise to two time scales. A first forward difference discrete model is developed for the continuous system considered. SPM is applied to this DC servo system for BVP, IVP and optimal control. The simulation results that obtained justify the proposed method. The same system may be considered for closed loop optimal control with one parameter as future work.

\section{References}

[1] Saksena V. R., O’Reiley J. and Kokotovic P. V., Singular perturbations and time-scale methods in control theory: Survey 1976-1983, Automatica(1984), 20: 273-293.

[2] Yong Chen and Yongqiang Liu, Summary of Singular perturbation modeling of multi-time scale power systems, In 2005 IEEE/PES Transmission \& Distribution Conference \& Exposition: Asia and Pacific. Dalian, China: IEEE. pp. 1-4.

[3] Koichi F. and Kunihiko K, Bifurcation cascade as chaotic itinerancy with multiple time scales, Chaos: An Interdisciplinary J Nonlinear Science (2003), 13: 1041-1056.

[4] F. Hoppensteadt and W. Miranker, Multitime methods for systems of difference equations, Stud. Appl. Math., vol. 56, pp. 273-289(1977).

[5] D. S. Naidu, Singular Perturbations and Time Scales in Control Theory and Applications: An Overview, Dynamics of Continuous, Discrete and Impulsive Systems Series B: Application and Algorithm(2002), 9, 2, 233-278. ISSN: 1492-8760.

[6] Adel Tellili, Nouceyba Abdelkrim. Diagnosis of discrete-time singularly perturbed systems based on slow subsystem. ACTA Mechanical Automatica(2014); 8: 175-180. 
[7] Dongdong Zheng, Wen-Fang Xie, Identification and control for singularly perturbed systems using multitime-scale neural networks, IEEE T on Neural Networks and Learning Systems(2017); 28: 321333.

[8] Rajasekhar Ananthoju, A. P. Tiwari, and Madhu N. Belur, A Two-Time-Scale Approach for DiscreteTime Kalman Filter Design and Application to AHWR Flux Mapping. IEEE $\mathrm{T}$ on Nuclear Sci. (2016); 63: 359-370.

[9] Magdi S. Mahmoud , Yuliu Chen \& Madan G. Singh, Discrete two-time-scale systems, International Journal of Systems Science, 17:8, 1187-1207(1986),

doi: $10.1080 / 00207728608926881$.

[10] Hardev Singh, Ronald H. Brown, D. Subbaram Naidu., Discrete-time timescale analysis via a new separation ratio and unified approach, International Journal of Systems Science 34:6(2003), pages 403412.

[11] Patre, B. M., \& Bandyopadhyay, B., Robust Control for Two-Time-Scale Discrete Interval Systems, Reliable Computing, 12(1), 4558(2006), doi:10.1007/s11155-006-2971-x

[12] E. C. Bekir, Singular perturbation methods for discrete time systems, in Proc. IEEE Conf. Decis. Control(1985), vol. 24, pp. 86-94.

[13] R. G. Phillips, Reduced order modelling and control of two-timescale discrete systems, Int. J. Control, vol. 31(1980), pp. 765-780.

[14] D.S Naidu, and D.B Price, Singular perturbations and time scales in the design of digital flight control systems, NASA Technical paper 2844. 1988, doi:10.1007/BFb0015123.

[15] Naidu, D. S., \& Kailasa Rao, A., Singular perturbation method for initial-value problems with inputs in discrete control systems. International Journal of Control, 33(5), 953965(1981). doi:10.1080/00207178108922967

[16] K.W. Chang, Singular perturbations of a general boundary value problem, SIAM J. Math. Anal. 3 (1972), 520-526.

[17] Krishnarayalu, M. S. and Naidu, D. S., Singular perturbation method for boundary value problems in two-parameter discrete control systems, Int. J. Systems Sci. 19 (1988) 2131-2143.

[18] Vasil'eva, A.B., Dmitriev, M.G. Singular perturbations in optimal control problems. J Math Sci 34, 1579-1629

(1986). doi:10.1007/BF01262406

[19] Dmitriev M. and Kurina G. Singular perturbations in control problems. Automation and Remote Control Volume 67,Issue 1 (2006), pp 1-43, doi:10.1134/S0005117906010012.

[20] M. Bidani, N. E. Radhy, B. Bensassi, Optimal control of discrete-time singularly perturbed systems, International Journal of Control 75:13, pages 955-966(2002).

[21] Robert R. Wilde and Petar V. Kokotović, Optimal open-and closed-loop control of singularly perturbed linear systems, IEEE Trans. Automatic Control AC-18 (1973), 616-626.

[22] P.J. Moylan and J.B. Moore, Generalizations of singular optimal control theory, Automatica J. IFAC 7 (1971), 591-598.
[23] Marvin I. Freedman and James L. Kaplan, Perturbation analysis of an optimal control problem involving Bang-Bang controls, J. Differential Equations 25 (1977), 11-29.

[24] Sannuti, P. and Reddy, P. Optimal control of a coupled-core nuclear reactor by a singular perturbation method, IEEE Transactions on Automatic Control, 20(6), 766- 769(1975), doi:10.1109/tac.1975.1101096.

[25] G. K. Babu and M. S. Krishnarayalu, Suboptimal control of singularly perturbed multiparameter discrete control system, 2015 International Conference on Power, Instrumentation, Control and Computing (PICC), pp. 1-8(2015), doi: 10.1109/PICC.2015.7455794.

[26] Krishnarayalu M. S. and Kishore Babu G., Shooting Methods for Two-Point Boundary Value Problems of Discrete Control Systems. International Journal of Computer Applications, Volume 111 - No 6(2015), pp 16-20, doi:10.5120/19543-1394.

[27] Jide Julius Popoola1, Modelling and Simulation of Armature-Controlled Direct Current Motor Using MATLAB. SSRG International Journal of Electrical and Electronics Engineering (SSRG-IJEEE) volume 2 Issue 3. pp 1-18(2015), ISSN: 2348 8379.

[28] Kurina G., Nguyen Thi Hoai, Zero-Order Asymptotic Solution of a Class of Singularly Perturbed Linear-Quadratic Problems With Weak Controls in a Critical Case, Optim. Control Appl. Methods, 40:5 (2019), 859-879.

[29] Kurina G., Nguyen Thi Hoai, Higher Order Asymptotic Approximation to a Solution of Singularly Perturbed Optimal Control Problem With Intersecting Solutions of the Degenerate Problem, $23^{\text {rd }}$ International Conference on System Theory, Control and Computing (ICSTCC), International Conference on System Theory Control and Computing, ed. Precup R., IEEE(2019), 727-732.

[30] G. A. Kurina, Asymptotic solution of singularly perturbed linear-quadratic optimal control problems with discontinuous coefficients, Comput. Math. Math. Phys., 52:4 (2012), 524-547

\section{Contribution of Individual Authors to the Creation of a Scientific Article (Ghostwriting Policy)}

The authors equally contributed in the present research, at all stages from the formulation of the problem to the final findings and solution.

Sources of Funding for Research Presented in a Scientific Article or Scientific Article Itself

No funding was received for conducting this study.

\section{Conflict of Interest}

The authors have no conflicts of interest to declare that are relevant to the content of this article.

Creative Commons Attribution License 4.0 (Attribution 4.0 International, CC BY 4.0)

This article is published under the terms of the Creative Commons Attribution License 4.0 https://creativecommons.org/licenses/by/4.0/deed.en 